Contents list avaliable at Directory of Open Access Journals (DOAJ)
Aulad : Journal On Early Childhood
Vol 3 No 2 2020, Pages 103-114
ISSN : 2655-4798 (Printed); 2655-433X (Online)
Journal Homepage: https://aulad.org/index.php/aulad

\title{
Pre-school Teachers' Beliefs towards Their Abilities of Teaching English to Pre-schoolers in Pahang, Malaysia
}

\author{
Aisyah Khaleeda Rosli ${ }^{1}$ \\ Centre for Modern Languages, Universiti Malaysia Pahang, \\ Pekan, Pahang, Malaysia \\ Noor Raha Mohd Radzuan² \\ Centre for Modern Languages, Universiti Malaysia Pahang, \\ Pekan, Pahang, Malaysia \\ DOI: 10.31004/aulad.v3i2.66
}

\section{Article Info}

Keywords:

Teachers'beliefs

English proficiency

Pre-schools

Self-efficacy

$E L T$

\section{Abstract}

In the education sector, teachers serve as the most important role model in improving learners' English language competency. Due to this, the beliefs of the pre-school teachers initiate a critical indicator in deciding if, given the circumstances, pre-school children can receive adequate English inputs and exposure at their age. In this study, 60 private pre-school teachers were given a set of questionnaires consisting of 14 items to investigate their beliefs towards their abilities of teaching English to pre-schoolers in Pahang, Malaysia. The findings of this study revealed a much more positive view of teachers' beliefs in pre-school English teachings. This can become a stimulus for the growth of English proficiency among Malaysian children and consequently improve the standard of English in Malaysia in the future.

\section{Abstrak}

Kata kunci: Keyakinan guru

Kemahiran bahasa Inggris Pra-sekolah

Efikasidiri

$E L T$

Di sektor pendidikan, guru berperanan sebagai model paling penting dalam meningkatkan kompetensi bahasa Inggris peserta didik. Karena itu, kepercayaan guru-guru prasekolah memulai indikator kritis dalam memutuskan apakah, mengingat keadaannya, anak-anak prasekolah dapat menerima input bahasa Inggris yang memadai dan paparan pada usia mereka. Dalam studi ini, 60 guru prasekolah swasta diberikan seperangkat kuesioner yang terdiri dari 14 item untuk menyelidiki keyakinan mereka terhadap kemampuan mereka mengajar bahasa Inggris kepada anak-anak prasekolah di Pahang, Malaysia. Temuan penelitian ini mengungkapkan pandangan yang jauh lebih positif dari keyakinan guru dalam pengajaran bahasa Inggris pra-sekolah. Ini dapat menjadi stimulus untuk pertumbuhan kecakapan bahasa Inggris di antara anak-anak Malaysia dan akibatnya meningkatkan standar bahasa Inggris di Malaysia di masa depan.

\footnotetext{
${ }^{1}$ Msc Language Education, Centre for Modern Languages, Universiti Malaysia Pahang, Malaysia.

Email: aisyahkhaleeda@yahoo.com

${ }^{2}$ Associate Professor, Centre for Modern Languages, Universiti Malaysia Pahang, Malaysia.

Email:nraha@ump.edu.my
} 


\section{INTRODUCTION}

Malaysia is amongst other Association of Southeast Asian Nations (ASEAN) developing countries with the reading of human development index (HDI) at 0.804 (United Nations Development Programme, 2019). In Malaysia, English is considered an important language to be learned. Being a proficient English language speaker has become one of the requirements that can increase the employability rate of an individual, especially for those who are applying for jobs at private sector companies (Ting et al., 2017). Many are aware that although Bahasa Melayu is the national language of the country, English as a second language (L2) in Malaysia acts an important instructional language, trade language and is vastly used in the education system (Melitz, 2016).

According to Carvalho, Sivanandam, Rahim and Tan (2019), evidently, individuals with a strong command of English language are likely to enjoy more benefits and privileges in the current era than their less competent peers. Other than that, there is no denying the role of language education as the dominant contributor to increasing literacy among the population of the country. High level of literacy in a country reflects the effectiveness of the country's education system. On the other hand, high rates of illiteracy among the population are often associated with social problems such as poverty and recession (Cabus \& De Witte, 2015) therefore improving the quality of literacy among the people of a country will be an effort for the betterment of human development which at the same time contributing to the country's economic, social and political development.

English, a second language in Malaysia, was formally taught and included as a syllabus in the system as early as pre-school education. At the primary school level in Malaysia, English must be taken by all students from standard one through to the standard six. English is taught to equip students with English language skills to enable them to pursue higher education as well as fulfilling their career requirements. By mastering English, students can also access information from the Internet and can interact with their fellow colleagues locally and overseas to experience authentic learning. In addition, according to the previous 7th Prime Minister of Malaysia, Tun Dr. Mahathir Mohamad, the country's ability to survive and thrive would be in jeopardy if the future generation is not well-versed in English, the language of trade and commerce (Carvalho et al., 2019).

Quoted from Tun Mahathir (Azil, 2020), "They (the knowledge of Science and Math) mostly came from the outside. Most knowledge came to this country via English language and for that purpose we will use English to educate and teach science and mathematics." Although the policy has been abolished in 2012 due to the claim of it being an infringement to the Malaysian heritage by Malay nationalists and Chinese educationists, Tun Mahathir has again decided to consider reversing the PPSMI abolishment hence acknowledging the importance of mastering English to the citizens in the long run. Several examples over the time have shown the immense importance of English; after years of operation worldwide, the Japanese manufacturing car company Honda has finally made English its corporate lingua franca (Greimel, 2015).

Many Malaysians today understand that learning English is crucial in order to succeed in the present era. Local researchers tried to resolve the arising problems of English as Second Language (ESL) studies among Malaysians in order to find out the best possible way for people to learn English. In one of the ESL studies, a researcher came up with four important findings that could possibly influence language learning (Shafa, 2015). The findings include learners' motivation, the age of the learners, the method of teaching and learning, and the first language of the learner. Do note that the age of learners is mentioned by Shafa (2015) as one of the factors that can influence language learning. This is where the current study stepped in to explore further into the matter of learners' age and English language acquisition.

In Malaysia, one of the most discussed topics regarding ESL is on how to improve the quality of English learning starting from early childhood education (ECE) (Othman \& Kiely, 2016). This is because the primary process of L2 learning and mastery is found to be crucial at an early age as Friedmann and Rusou (2015) has confirmed that "children have the ability to acquiring a language, syntax and phonology since the day they were born" (p. 27). Also, Hartshorne Tenenbaum and Pinker (2018) stated that "those who have acquired a second language in infancy are hard to distinguish from native speakers, while those who have begun in adulthood are often saddled with accentuated and noticeable grammatical errors" (p. 263).

Due to this, the focus of current study falls within the horizon of ECE. Furthermore, past studies have proven that teachers' beliefs could become important leverage in the development of new educational policy, especially in the area of ECE regarding the learning of English hence improving the quality of English proficiency amongst the learners of English in a non-native speaker country (Mohamed \& Al-Qaryouti, 2016; Nafissi \& Shafiee, 2019; Yang, 2019). This study explores pre-school teachers' beliefs in their ability to teach English to pre-schoolers in Pahang, an East coast state located in Peninsular Malaysia.

\section{THEORY}

\section{Pre-school Education in Malaysia}

Increased number of pre-schools is a good indicator of educational development in Malaysia. In 1996, the government had recommended that pre-school education should be based on the national education policy (Malaysia Education Blueprint, 2013). However, the idea was not considered new since pre-school education has already been a part of the national education system for a while. National Pre-school Curriculum (NPC) is one of 
the proofs. The main reason why the recommendation was put forward was to ensure that the learning and teaching of English can start early. The step taken by the government was not only to act as a boost to the quality of local pre-schools but also as a golden opportunity for pre-school teachers to teach English in a creative manner. It is also well-acknowledged that childhood is a critical year in which acquisition of knowledge is accelerated (Bedore et al., 2016; R. Hu, 2016; Schlueter, 2019). Thus, providing comprehensive pre-school level stimulation to learn English is very effective for enriching the mind of the children.

Other than that, a study shows that young children, especially infants, are sensitive to their environment and can learn two or three languages simultaneously including international languages (Byers-Heinlein \& LewWilliams, 2013). If the learning and teaching of English occurred in pre-school, teachers are encouraged to first master the language. Involvement and cooperation from the Ministry of Education are important as not all preschool teachers in Malaysia are fluent in English. Many aspects including teachers' beliefs, the abilities of teachers, the school environment and location and the children's background must be given extra consideration by the MOE in order to enhance the quality of English proficiency amongst Malaysians.

The government's proposal to implement English at pre-school level is considered very appropriate as English is crucial in Malaysia especially in academic and occupational areas. The usage of English in pre-schools will provide a positive impact on language proficiency, especially among children who will indeed make English as L2 in the future. At present, estimated total of pre-school teachers working in private sectors all over Malaysia are 30,372 (Ismail et al., 2018). Current study, however, focuses only on private pre-school teachers in Pahang, Malaysia. A total of 83 private pre-school teachers who registered under the early childhood educators' associations in Pahang became the population of the research.

\section{Teachers' Beliefs in the Context of Language Learning}

In order to improve the educational quality of English teaching and learning, beliefs of teachers need to be explored and understood. Other areas of English (such as teaching techniques, English modules, reading techniques and grammar) have vastly been explored by local and foreign researchers, yet few research has been conducted to explore the beliefs of teachers teaching English, especially in Pahang, Malaysia. Being an abstract concept, beliefs are known to closely guide language teachers to adjust their teaching strategies to suit their daily language teaching techniques, influence their overall behaviours, and in turn shape the learning environment of language learners, their motivation, and their language achievement and ability (Lomas \& Clarke, 2016; Vosniadou, 2019).

The beliefs of teachers function as perceptual screens filtering their perceptions and influencing their thoughts and actions. Beliefs concerning students, teaching and learning guide the preparation of teachers and their moment-to-moment decisions regarding class scheduling, instructional methods, student relationships and evaluation (Klassen et al., 2020). There is increasing evidence that teachers are profoundly motivated by their beliefs, which are in turn closely related to their values, their world views, and their sense of place. In the area of belief, the concept of belief has been explained in detail by Borg (1998). He claimed that the knowledge, theories, attitudes, images, assumptions, metaphors and beliefs are within the teacher's cognition. In addition, beliefs can be in correlation with teaching, teachers, learning, students, subject matter, curricula, materials, instructional activities and self (Borg, 1998). In other words, teachers' beliefs could affect language teaching practice, learners' experience, selection of materials and teachers' self-confidence in a classroom.

Bhuvaneswari (2016) referencing Borg (1998) stated that young learners believe everything their teachers believe in and the belief system of the teacher may either persuade or dissuade a student. The topic of teachers' beliefs has received considerable interest in the field of English Language Learning (ELL) and became an important focus for past research (Bandura, 1997; Farrell \& Bennis, 2013; Farrell \& Ives, 2015). However, belief is considered as a complicated concept and complex to be understood because belief cannot be seen with naked eyes unless the teachers make statements for themselves. Upon research, teachers' beliefs are highly influential to classroom practices (Borg, 1998). To further strengthen the statement, Chen, McCray, Adams and Leow (2014) stated that teachers' beliefs affect learning priorities and this is supported by past research (Bandura, 1997; Reber \& Greifeneder, 2017).

The research conducted by Chen et al. (2014) investigates the beliefs of pre-school teachers in early Math learning. In the research, three elements are being discussed: (1) Teachers' beliefs about pre-schoolers and math; (2) teachers' confidence in helping pre-schoolers learn math; (3) teachers' confidence in their personal math abilities. These three elements are developed into questionnaires and are given to pre-school teachers in the Midwest. The research reported that for children to gain complete math understanding, their teachers must feel confident in teaching math and be mathematically proficient. Although the study by Chen et al. (2014) explored the area of mathematics, the same exploration can also be done with the teaching of English.

\section{Teachers' Self-Efficacy Theory}

Teachers' beliefs are frequently discussed and placed in the same area of teachers' self-efficacy. In regards to teachers' beliefs and confidence, self-efficacy is a term that has been coined by Bandura (1997) under social 
cognition theory. In the theory of self-efficacy, Bandura (2013) quotes Bandura (1988), "The stronger the belief in their capabilities, the greater and more persistent are their efforts" (p. 365). He argued that while people may know that certain achievements lead to desired outcomes, this information becomes useless when they lack the beliefs that they have the ability to produce such actions. Thus, personal self-efficacy beliefs seem to be the most important cause of human behaviour (Bandura, 1997).

Another study conducted on teachers' self-efficacy has also proven that self-efficacy beliefs can influence teachers' commitment to the teaching profession (Chesnut \& Burley, 2015) which suggests that teacher's belief is important to be explored in order to develop a high quality language learning environment. Nevertheless, even when teachers recognize that a given approach can be more effective in teaching, their efficacy beliefs for enacting the new method can guide their decisions on implementation.

In a different study, Zee and Koomen (2016) explored the consequences of teachers' self-efficacy for the quality of classroom processes, students' academic adjustment and teachers' psychological well-being. Results from their study suggest that teachers' self-efficacy shows positive correlation with students' academic adjustment, patterns of teachers' behaviour and practices related to classroom quality, and factors underlying teachers' psychological well-being, including personal accomplishment, job satisfaction and commitment.

Ford (2013) conducted a quantitative study examining the factors affecting the effectiveness of urban teachers' efficacy and their ability to motivate urban students inside their classroom. The key factor found in the study is teachers' self-efficacy. Five frameworks have been built in the study: motivation, administrative support, teachers' power, teachers' confidence, and the teaching method. On the basis of the findings, the researcher found that there were significant differences in all frameworks that supported the fact that efficacy measurements indeed influence students' motivation. With mentioned study on teachers' self-efficacy by Ford (2013), current study would concentrate on the pre-school teachers situated on the periphery of urbanization on the east coast of Peninsular Malaysia instead of looking at teachers who teach in urban settings.

\section{Pre-school Teachers' Beliefs}

Teachers' beliefs are important for understanding and enhancing the education system. Teachers' beliefs closely direct language teachers to follow their teaching strategies to tackle the difficulties of their day-to-day language teaching, affect their overall behaviours, and successively shape language learners' learning environment, enthusiasm, and language achievement and skill (Xu, 2012). Belief falls within the context of teachers' cognition where there is awareness, ideas, perceptions, pictures, beliefs, metaphors, impressions, and viewpoints (Borg, 1998). In fact, there may be a correlation of beliefs with instruction, instructors, schooling, pupils, subject matter, curricula, content, educational activities, and self. In other words, the teachers' beliefs may influence the practice of language teaching, the experience of learners, the collection of materials and the trust of teachers in themselves.

In a more recent study by B. Y. Hu, Fan, Yang and Neitzel (2017) a discussion was prompted regarding the relationship between teachers' knowledge about effective teacher-child interactions, beliefs about children, and observed teacher-children interaction practice in Chinese kindergartens. Findings of their study imply that there is a significant association between teachers' knowledge, beliefs, and emotional/instructional practice; the mediating role of teachers' beliefs on the relationship between knowledge and behavioural/instructional practice; (c) that years of teaching experience and degree are predictors for teachers' beliefs. The results offer important implications about how to prepare teachers and foster their child-centred beliefs through professional development.

\section{METHODS}

The method that is used for the study is a quantitative method as it enables researchers to evaluate numerical data gathered from the questionnaire and later analysed with statistical analysis (Creswell \& Creswell, 2018).

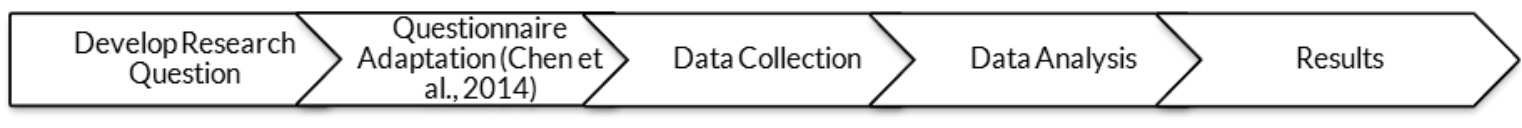

Fig. 1. Block Diagram of Quantitative Method Research Design

In this study, a purposive sampling method is utilized. Purposive sampling method is used when the researcher relies on his or her own judgment when selecting population representatives (Saunders et al., 2016). This study utilizes purposive sampling to ensure that the samples selected will help answer research questions or accomplish research goals. 


\section{Study Participants}

To gather the data, samples for the research will be drawn from private pre-school teachers who registered under early childhood educators' association from each three East Coast states in Peninsular Malaysia - Pahang Early Childhood Educators Association (PECEA).

Table 1. Sample of Respondents

\begin{tabular}{ccc}
\hline State & Association & Pre-school Teachers (Population) \\
\hline Pahang & PECEA & 83 \\
\hline
\end{tabular}

Referring to the sampling method of Krejcie and Morgan (1970), a total of 60 pre-school teachers are chosen to become the sample for the research. Consents from each participant is obtained beforehand. Table 1 shows the population of the sample. The sample was selected through purposive sampling, as it is said to be useful in investigating anthropological circumstances (Saunders et al., 2016) which in this study, the teachers located in the eastern coast of Peninsular Malaysia becomes the main focus, specifically, Pahang.

\section{Early English and Confidence Survey (EEBCS)}

The sample was then given a set of Early English Beliefs and Confidence Survey (EEBCS) questionnaire adapted from Chen et al. (2014). The validity of the adapted questionnaire is tested through pilot study and the Cronbach alpha value showed a 0.9 which suggested a high validity point. For current study, EEBCS is used to measure pre-school teachers' beliefs. The questionnaire is personally administered by the researcher. Personally administered questionnaire is chosen as the instrument to collect quantitative data due to its efficiency in collecting a large number of complete responses from respondents within a short period of time (Sekaran \& Bougie, 2016). Teachers were asked to complete questionnaires that included demographic information (e.g., age, education, working experience), as well as beliefs about their ability of teaching English to pre-schoolers. The questionnaire consisted of 14 items and is formatted in a form of 5-Likert scale. Other than that, it is also designed to have three sub-sections: (1) teachers' beliefs in their abilities to teach English to pre-schoolers, (2) teachers' beliefs in their pedagogical practices for pre-school English and (3) teachers' beliefs in their personal English abilities.

\section{Measures and Procedure}

The study began with an adaptation of the questionnaire from Chen et al. (2014) The questionnaire consisted of 14 items of five-point Likert scale. 60 pre-school teachers are chosen to become the population of the study. The study started with the questionnaire being distributed to chosen respondents, where the gathering of quantitative data occurred. The aim of the questionnaire is to draw broad assumptions about the beliefs of teachers towards their ability to teach English to pre-schoolers. After the process of questionnaire adaptation, pilot study is first conducted to test the validity and reliability of the questionnaire. 15 pre-school teachers in Kuantan were given the adapted questionnaire through Google Forms as it is convenient for the researchers and the participants.

During the period of conducting the pilot study, some questions are discarded and replaced with new questions based on their relevance and suitability to the current study. Certain terms were also replaced to suit the current study environment. After the evaluation of the Cronbach alpha value of the questionnaire, the researchers found that the questionnaire has obtained a high validity value of 0.9 Cronbach alpha (Cronbach, 1951). Upon the completion of the pilot study, the study is then proceeded with the researchers distributing the questionnaires to 60 pre-school teachers located all over Pahang with the cooperation from PECEA. Within three weeks, the questionnaires are returned (response rate $=100 \%$ ). All respondents were female teachers.

\section{Data Analysis}

IBM Statistical Package for Social Science (SPSS) version 24 is utilized for quantitative analysis in order to manage the statistical data and conduct the descriptive statistical analyses. Questionnaire responses are considered as quantitative data where mathematical calculation will be involved in order to get a scientific value of the researched data such as mean and standard deviation. The major focus of quantitative study is to gather numerical data and generalize it across groups of people (Creswell \& Creswell, 2018). In this study, descriptive statistics is employed to describe the computed data which is collected from the EEBCS questionnaire. Statistical tool technique used to analyze quantitative data is presented in Table 2. 
Table 2. Research questions and statistical tools techniques used in analyzing quantitative data

\begin{tabular}{lll}
\hline No. & Research Questions & Statistical Tool Technique \\
\hline 1. & $\begin{array}{l}\text { To what extent do the pre-school teachers } \\
\text { believe in their abilities of teaching English to } \\
\text { pre-schoolers? }\end{array}$ & $\begin{array}{l}\text { Descriptive Analysis } \\
\text { (Mean \& Standard } \\
\text { Deviation) }\end{array}$ \\
\hline
\end{tabular}

Descriptive statistics, in short, helps to describe and understand the features of a specific data set by giving short summaries about the sample and measures of the data (Blummer \& Kenton, 2014). With SPSS, calculation of Cronbach alpha value for pilot study can be obtained easily. Other than that, upon using SPSS, mean and standard deviation of the questionnaire data were obtained.

\section{RESULT AND DISCUSSION}

This section will present the results obtained from the questionnaire distributed to the sample of the study followed by the discussion on the result.

\section{Teachers' Demographic Background}

Table 3 shows the descriptive statistics of demographic background of the pre-school teachers in Pahang $(N=60)$. Firstly, demographic data is obtained from respondents through demographic surveys. Based on the information retrieved, teachers' characteristics are tabulated based on three important indicators in the demographic form as shown in Table 3.

Table 3. Teachers' demographic information

\begin{tabular}{l|c|c}
\hline \multicolumn{3}{c}{ Teachers' Characteristics } \\
\hline \multirow{4}{*}{ Teachers' Age } & Variations & \multicolumn{1}{c}{$\begin{array}{c}\text { Frequency } \\
\text { (\%) }\end{array}$} \\
\cline { 2 - 3 } & $<20$ years old & 16.7 \\
\cline { 2 - 3 } & $21-25$ years old & 26.7 \\
\cline { 2 - 3 } & $26-30$ years old & 33.3 \\
\cline { 2 - 3 } & $31-35$ years old & 6.7 \\
\cline { 2 - 3 } & $36-40$ years old & 10 \\
\cline { 2 - 3 } Highest Academic Qualification & 40 years old $>$ & 6.7 \\
\hline & SRP/PMR/PT3 & 6.7 \\
\cline { 2 - 3 } & SPM & 36.7 \\
\cline { 2 - 3 } & Diploma & 30 \\
\cline { 2 - 3 } & Degree & 23.3 \\
\hline \multirow{5}{*}{ Years of working experience } & Masters & 3.3 \\
\cline { 2 - 3 } & $<1$ year & 16.7 \\
\cline { 2 - 3 } & $1-3$ years & 36.7 \\
\cline { 2 - 3 } & $4-6$ years & 13.3 \\
\cline { 2 - 3 } & $7-9$ years & 23.3 \\
\hline
\end{tabular}

There are three components extracted from the demographic survey (see Table 3). The three components include teachers' age, highest academic qualification and years of working experience. In term of teachers' age, about $33.3 \%$ of the teachers are in the $26-30$ age group, followed by $26.7 \%$ of them ranged between 21 - 35 years old, $16.7 \%$ in the $<20$ years old age group, $10 \%$ aged between $36-40$ years old, $6.7 \%$ aged between $31-35$ years old and only another $6.7 \%$ ranged above 40 years old. The highest percentage of teachers' age contributed from those who aged between 26 to 30 years old. In terms of academic qualification, many of the teachers became preschool teachers with having just SPM as their highest academic qualification (36.7\%), followed by Diploma holders (30\%) and Bachelor Degree in various courses (23.3\%) while few $(6.7 \%)$ hold SRP/PMR/PT3 certificate and only one person (3.3\%) got a Master Degree.

Referring to a past research, private pre-schools regulated by the Ministry of Education (MOE) Malaysia have less than $10 \%$ of their teachers qualified with the Diploma in early childhood education (Foong et al., 2018) in which has become a concern as level of education of pre-school teachers are important to be looked at. With regard to years of working experience of the pre-school teachers, 36.7\% of the respondents had between 1 to 3 years of work experience. $23.3 \%$ of them have been working as pre-school teachers for 7 to 9 years while $16.7 \%$ of the teachers have been teaching at pre-school for less than a year. Apart from that, $13.3 \%$ of the teachers have been working as pre-school teachers for 4 to 6 years and 10\% have been pre-school teachers for more than 10 
years. That is to say, a large percentage of the respondents were quite experienced as pre-school teachers as the majority of them have gained more than a year of experience at being teachers at pre-school.

\section{Teachers' Beliefs in Their Abilities to Teach English to Pre-schoolers}

Teachers were asked to rate their agreement and disagreement towards the survey items through the five points Likert scale in the EEBCS questionnaire. The results presented in Table 4 and Table 5 will present the mean (M) value and standard deviation (S.D.) of each item statement. In the descriptive result, research question is revisited. In EEBCS, the items of the questionnaire are divided into three subsections where the first section will focus on teachers' beliefs in their general English abilities, the second section focuses on pedagogical practices while the last section focuses on teachers' personal English abilities. In provided tables (Table 4, Table 5 and Table 6), the items have been arranged based on its mean value from the highest value to the lowest for systematic reading of readers.

Table 4. Teachers' beliefs in their abilities to teach English to pre-schoolers

\begin{tabular}{|c|c|c|c|}
\hline \multicolumn{2}{|c|}{ Item } & M & S.D. \\
\hline \multicolumn{4}{|c|}{ I am confident in my knowledge of } \\
\hline Q4 & ...the best assessment for English proficiency of pre-schoolers & 3.90 & 0.66 \\
\hline Q3 & ...the best practices and strategies for helping pre-schoolers learn English & 3.73 & 0.74 \\
\hline Q1 & ...what the children in my classroom know about English when they enter pre-school & 3.63 & 0.85 \\
\hline \multirow[t]{2}{*}{ Q2 } & ...reasonable English goals for pre-schoolers (able to read and write) & 3.57 & 0.86 \\
\hline & Total Average & 3.71 & 0.78 \\
\hline
\end{tabular}

In the first section of the questionnaire, teachers were asked to rate their beliefs in their knowledge and abilities to teach English to pre-schoolers (see Table 4). In term of their beliefs in the knowledge of teaching English to pre-schoolers, majority of the teachers $(M=3.90, S . D .=0.67)$ are confident in their knowledge of preparing the best assessment for English proficiency of pre-schoolers and many of them ( $M=3.73$, S.D. $=0.74)$ also believe that they can provide the best practices and strategies for helping pre-schoolers learn English. Other than that, the teachers $(M=3.63$, S.D. $=0.85)$ are found to be confident in their knowledge of what the children know about English when they enter pre-school. In addition, the result also demonstrates that the teachers understood reasonable English goals for pre-schoolers to achieve $(M=3.57$, S.D. $=0.86)$. Overall, the vast majority of the participants agreed that they are knowledgeable regarding the English contents to be taught to the pre-schoolers as the highest $\mathrm{M}$ value is 3.90 and the lowest is 3.57.

Table 5. Teachers' beliefs in their pedagogical practices for pre-school English

\begin{tabular}{|c|c|c|c|}
\hline \multicolumn{2}{|c|}{ Item } & M & S.D. \\
\hline \multicolumn{4}{|c|}{ I am confident in my ability to } \\
\hline Q8 & $\begin{array}{l}\text {...further pre-schoolers' English knowledge when they make spontaneous English } \\
\text { comments/discoveries }\end{array}$ & 4.07 & 0.74 \\
\hline Q9 & ...make sense of pre-schoolers' confusions when they learn English & 4.03 & 0.61 \\
\hline Q6 & $\begin{array}{l}\text {...incorporate English learning into common pre-school situations (such as art or dramatic } \\
\text { play) }\end{array}$ & 4.03 & 0.67 \\
\hline Q7 & ...plan activities to help pre-schoolers learn English & 4.03 & 0.85 \\
\hline \multirow[t]{2}{*}{ Q5 } & ...assess pre-schoolers' English knowledge and understanding & 3.80 & 0.71 \\
\hline & Total Average & 3.99 & 0.72 \\
\hline
\end{tabular}

For teachers' beliefs in their knowledge of pedagogical English practices, most of the teachers $(M=4.07$, S.D. $=0.74$ ) believe that they are able to further pre-schoolers' English knowledge when they make spontaneous English comments/discoveries. The teachers ( $M=4.03$, S.D. $=0.61)$ are also able to make sense of pre-schoolers confusions when learning English. Other than that, a large number of teachers $(M=4.03, S . D .=0.67)$ are confident that they are able to assess children. Additionally, the teachers $(M=4.03, S . D .=0.85)$ are also confident in their ability to plan activities that help pre-schoolers learn English. Lastly, several teachers ( $M=3.80, S . D .=0.70)$ of the teachers are also confident that they are able to further pre-schoolers' English knowledge when they make spontaneous English comments/discoveries while only 68.4\% ( $M=3.79$, S.D. $=0.78)$ of the teachers believe that they can make sense of pre-schoolers' confusions during English lessons. Finally, only $65.8 \%(M=3.76, S . D .=0.70)$ of the teachers are confident in their ability to assess pre-schoolers' English knowledge and understanding. In terms of teachers' beliefs in the pedagogical English practices, the big gap between highest and lowest mean values 
shows that there are teachers who are still in doubts of their pedagogical English practices. The highest $M$ value is 4.07 (Q8) while the lowest is 3.80 (Q5).

Overall result shows that in terms of general English skills and pedagogical methods, most teachers believe in their ability to teach English to pre-schoolers. Nonetheless, the number of teachers who rated 3 (agree) and above for each item in pedagogical English practices section is higher than in the number of teachers who rated 3 and above in the beliefs of general English knowledge section. In the last section of the questionnaire, teachers were asked to rate their beliefs in their own personal English abilities. The items consist of sentences that probe answers regarding their personal take on their own English skills and proficiency.

Table 6. Teachers' beliefs in their personal English abilities

\begin{tabular}{|c|c|c|c|}
\hline \multicolumn{2}{|l|}{ Item } & M & S.D. \\
\hline \multicolumn{4}{|c|}{ I believe that } \\
\hline Q10 & English was one of my best subjects in school & 3.57 & 0.90 \\
\hline Q11 & I can easily create English sentences. & 3.47 & 0.78 \\
\hline Q12 & I can translate Bahasa into English and vice versa easily & 3.47 & 0.68 \\
\hline Q13 & I can easily come up with item names in English & 3.40 & 0.81 \\
\hline \multirow[t]{2}{*}{ Q14 } & I am very good at pronouncing English words & 3.33 & 0.92 \\
\hline & Total Average & 3.45 & 0.82 \\
\hline
\end{tabular}

${ }^{\bar{M}} \mathrm{M}=$ Mean; S.D.= Standard deviation

Upon analysis, almost half of the teachers $(M=3.57$, S.D. $=0.90)$ find English to be their best subjects in school. Other than that, less than half of the teachers $(M=3.47$, S.D. $=0.78$ ) believe that they can easily create English sentences. In addition, some of the teachers ( $M=3.47$, S.D. $=0.68$ ) are confident that they can translate Bahasa into English and vice versa easily and some of them $(M=3.40, S . D .=0.81)$ can easily come up with item names in English. Lastly, in terms of pronunciation of English words, only few of the respondents $(M=3.33$, S.D. $=0.92$ ) are confident in their English pronunciation skill. Overall analysis indicates that the highest $M$ value is below 4.00 which is 3.57 while the lowest $M$ value is 3.33. It appears that the teachers are mostly not confident enough in their personal English abilities. The findings might or might not have a correlation with teachers' highest academic qualification which later will be discussed in the following section.

\section{Discussion}

To date, local research on the teachers' beliefs of English learning and teaching at pre-school is scarce. In this study, the researchers sought to understand the magnitude of pre-school teachers' beliefs towards their abilities of teaching English to pre-schoolers in Pahang. Upon obtaining the survey results, the researcher attempted to answer the research question - to what extent do pre-school teachers believe in their abilities to teach English to pre-schoolers? Questionnaire results revealed that a vast majority of the respondents believe that they are knowledgeable of what to teach for pre-school English and that they have the ability to teach it to young children. Based on the data obtained, the study concluded that $75 \%$ of the teachers are found to hold positive beliefs about their ability to teach English to pre-schoolers in Pahang. In reference to a research by Majzub (2013), pre-school teachers are generally portrayed as disliking English, lacking confidence and ability to teach early English, reluctant to teach it, trying to avoid teaching it, and "...hardly able to use English without any errors" (Majzub, 2013). In current study, questionnaire data has proven the opposite. Based on literature provided (Borg, 2018; Chen et al., 2014; Othman, 2019), positive teachers' beliefs can lead to positive classroom practices hence if many of Pahang pre-school teachers have positive beliefs in the teaching of English at pre-school level, the quality of English proficiency among the people living in Pahang can be considerably improved.

To add, from the findings, teachers show faith in their ability to provide best practices and strategies for helping pre-schoolers learn English. The fact that the pre-school teachers are believing in their abilities to teach English, Borg (2018) noted that teachers' beliefs may outweigh the effects of teacher education in influencing what teachers do in the classroom. Although academic qualification of the teachers can be questionable if it were to be compared to required qualification set by Malaysia MOE, the teachers are confident that they are able to provide sufficient English practices to the pre-schoolers which could be attributed to the many years of working experience and their positive beliefs. Based on demographic data, $85.1 \%$ of the respondents have more than a year of working experience, supporting Bandura (2013) self-efficacy framework where experience can have positive effects on a person's self-efficacy. Other than that, Borg (2003) did mention that teachers learn a lot about teaching through their vast experience as learners which validates the findings of current study. In addition, current findings also suggest that teachers believe that they are able to set goals and plan English lessons, integrate English learning into a variety of situations, and understand English goals for pre-schoolers. Since most of 
the teachers have taught in pre-school for more than a year, the teachers are already familiar with what needed to be assessed for English learning for pre-schoolers.

Apart from looking at teachers' beliefs in their abilities to teach English, teachers' beliefs in pedagogical practices is equally significant. Teachers' beliefs should be positive in accepting changes in educational innovation by striving to improve their self-confidence so that teaching and learning processes can work effectively and learning outcomes can be achieved (Mohd. Hamzah \& Attan, 2007). In this study, several teachers are found to be less optimistic about their knowledge on how to assess pre-schoolers' knowledge and understanding of English. Pre-school teachers find it difficult to assess English proficiency as the children that entered the pre-schools do not possess measurable English qualifications before they enter pre-schools such as MUET, IELTS or EPT where the proficiency level of a student can be apparent and tested (Abas, 2019; Kaur et al., 2019; Malaysian Examinations Council, 2016; Rashid et al., 2017; Rethinasamy \& Chuah, 2011; Sani, 2017). The difficulties in identifying the level of English proficiency of pre-schoolers causes the responses form the teachers varied. In Pahang, it is apparent that these private pre-school teachers faced challenges in determining the level of English proficiency of the pre-schoolers as there is no specific guideline provided by the education system in order to do so.

On the other hand, beliefs dictate how people feel, perceive, inspire, and act. Beliefs, according to Abdullah and Laji (2016), will influence the way a teacher works, thinks and acts on the environment. In this study, the beliefs of teachers in their personal English abilities varied. Based on the findings, the research can conclude that most private pre-school teachers in Pahang are not fully confident in their personal English knowledge. The research suggests positive correlation between teachers' confidence in their personal English abilities and their academic qualification and is supported by Nair, Hanafi and Yassin (2017)where "pre-school teachers with higher educational qualifications had significantly better classroom practices as compared to teachers with lower educational qualifications" (p. 93). In some cases, years of teaching experience could overcome the lack of confidence in teachers even though there is interference from academic qualification of the teachers.

Overall, the results of the questionnaire revealed that the confidence of Pahang teachers in their ability to teach pre-school English is greater than their confidence in their own ability to utilize English. This disparity between "technical" and "personal" English indicates pre-school teachers may not feel good at English, but they think they can teach reasonably well for pre-schoolers. The possibility that teachers may think early English is simple, quick, and needs little English knowledge to be taught is of concern with this finding. It is also possible that positive beliefs in helping children learn English comes from a long-established strength of teachers in early childhood; namely, understanding children well and feeling comfortable around children. The differences in highest and lowest value of mean $(M=4.07 ; M=3.33)$ indicates that teachers have areas of relative strength and weakness in both types of teacher beliefs - beliefs in teaching English and in their personal English skills - a finding that is particularly relevant to the area of teachers' cognitive.

This result is both a challenge and a chance to develop better pre-school English pedagogy. The challenge lies in the assumption that teaching early English is simple as it requires the most basic English. However, many may not realize that early English is basic, but not simple; it is more abstract, complex, and conceptual (Peter \& Chomsky, 1968). Strengthening the understanding of basic English by pre-schoolers, including big ideas - the core English concepts that lay the foundation for life-long English learning and thought in various content areas - is of critical importance to pedagogical effectiveness, and helping them form strong links between these ideas. Current study may help ECE sectors to gain general ideas on the general situation that is faced by private pre-school educators in Pahang, Malaysia.

\section{CONCLUSION}

While portrayals of early English teaching are generally negative, especially in Pahang, the results of this current study imply that most pre-school teachers in Pahang have competent strengths to teach English to preschoolers. Enhancement on these strengths will likely increase teachers' ability to teach beyond their comfort zone. Building on language skills can also boost the learning interest of pre-schoolers, which in turn increases the morale of teachers. Forming the educational teachers' beliefs in the language teaching-learning process will have an imperceptible impact on the development of successful language teaching methods and will contribute to an increase in the language competency of the pre-schoolers in Malaysia.

\footnotetext{
Abbreviations

ASEAN: Association of Southeast Asian Nations; HDI: Human Development Index; L2: Second Language; PPSMI: The Teaching of Mathematics and Science in English programme; ESL: English as Second Language; ECE: Early Childhood Education; MOE: Ministry of Education; NPC: National Pre-school Curriculum; PECEA: Pahang Early Childhood Educators Association; EEBCS: Early English Beliefs and Confidence Survey; SPSS: Statistical Package for Social Science
} 


\section{Acknowledgements}

The authors are grateful to Pahang Early Childhood Educators Association (PECEA) for their collaboration in providing participants for the research purpose. The authors are also thankful to the two anonymous reviewers for their careful reading of the manuscript and insightful comments.

\section{Authors' contributions}

The authors are responsible for this research. Both authors have substantially contributed to conceptualizing and designing the study, analysing the data, writing and revising the manuscript. Both authors read and approved the final manuscript.

\section{Funding}

This study is funded by Ministry of Education (MOE) Malaysia under the Fundamental Research Grant Scheme ((FRGS/1/2018/SSI09/UMP/02/6) - RDU190170 Developing CEFR-informed English Language Competency Framework for Pre-school Educators in the East Coast Economic Region [2019 - 2020] and PGRS200326 Teachers' Cognitive: Pre-school Teachers' Beliefs towards Their Abilities of Teaching English to Pre-schoolers in Pahang.

\section{Availability of data and material}

The datasets used and/or analysed during the current study are available from the corresponding author on reasonable request.

\section{Competing Interests}

The authors declare that they have no competing interests.

\section{REFERENCES}

Abas, A. (2019, May). MUET allows Education Ministry to gauge English teachers' proficiency. New Straits Times. https://www.nst.com.my/news/nation/2019/05/487439/muet-allows-education-ministry-gauge-englishteachers-proficiency

Abdullah, M. K., \& Laji, H. (2016). Analisis Perbandingan Efikasi Pengajaran dalam Kalangan Guru Bahasa Melayu Tahun Satu. Jurnal Pendidikan Bahasa Melayu.

Azil, F. (2020, January). Dasar PPSMI akan dikembalikan dalam sistem pendidikan negara - PM. Astro Awani. http://www.astroawani.com/berita-malaysia/dasar-ppsmi-akan-dikembalikan-dalam-sistem-pendidikannegara-pm-229496

Bandura, A. (1988). Self-Regulation of Motivation and Action Through Goal Systems. In Cognitive Perspectives on Emotion and Motivation. https://doi.org/10.1007/978-94-009-2792-6_2

Bandura, A. (1997). Teacher Self Efficacy Scale. Unpublished.

Bandura, A. (2013). Self-efficacy and social cognitive theories. PennState.

Bedore, L. M., Peña, E. D., Griffin, Z. M., \& Hixon, J. G. (2016). Effects of Age of English Exposure, Current Input/Output, and grade on bilingual language performance. Journal of Child Language. https://doi.org/10.1017/S0305000915000811

Bhuvaneswari, G. (2016). Teacher cognition. International Journal of Economic Research.

Blummer, B., \& Kenton, J. M. (2014). Methodology: the data analysis. In Improving Student Information Search. https://doi.org/10.1533/9781780634623.125

Borg, S. (1998). Teachers' Pedagogical Systems and Grammar Teaching: A Qualitative Study. TESOL Quarterly. https://doi.org/10.2307/3587900

Borg, S. (2003). Teacher cognition in language teaching: A review of research on what language teachers think, know, believe, and do. Language Teaching. https://doi.org/10.1017/S0261444803001903

Borg, S. (2018). Teachers' Beliefs and Classroom Practices. In P. Garrett \& J. M. Cots (Eds.), The ROutledge Handbook of Language Awareness. Routledge.

Byers-Heinlein, K., \& Lew-Williams, C. (2013). Bilingualism in the Early Years: What the Science Says. LEARNing Landscapes. https://doi.org/10.36510/learnland.v7i1.632

Cabus, S. J., \& De Witte, K. (2015). Does unauthorized school absenteeism accelerates the dropout decision? Evidence from a Bayesian duration model. Applied Economics Letters. https://doi.org/10.1080/13504851.2014.937031

Carvalho, M., Sivanandam, H., Rahim, R., \& Tan, T. (2019, July). Dr M: Put aside nationalist pride, allow English in teaching of science, maths. The Star Online. https://www.thestar.com.my/news/nation/2019/07/16/dr-mput-aside-nationalist-pride-allow-english-in-teaching-of-science-maths/

Chen, J. Q., McCray, J., Adams, M., \& Leow, C. (2014). A Survey Study of Early Childhood Teachers' Beliefs and Confidence about Teaching Early Math. Early Childhood Education Journal. https://doi.org/10.1007/s10643-013-0619-0 
Chesnut, S. R., \& Burley, H. (2015). Self-efficacy as a predictor of commitment to the teaching profession: A metaanalysis. In Educational Research Review. https://doi.org/10.1016/j.edurev.2015.02.001

Creswell, J. W., \& Creswell, J. D. (2018). Research and Design Qualitative, Quantitative and Mixed Methods Approaches. In Thousand Oaks California.

Cronbach, L. J. (1951). Coefficient alpha and the internal structure of tests. Psychometrika. https://doi.org/10.1007/BF02310555

Farrell, T. S. C., \& Bennis, K. (2013). Teachers believes in classroom practices. RELC Journal.

Farrell, T. S. C., \& Ives, J. (2015). Exploring teacher beliefs and classroom practices through reflective practice: A case study. Language Teaching Research. https://doi.org/10.1177/1362168814541722

Foong, L., Veloo, P. K., Dhamotharan, M., \& Loh, C. (2018). Private sector early child care and education in Malaysia: Workforce readiness for further education. Kajian Malaysia. https://doi.org/10.21315/km2018.36.1.6

Ford, I. R. (2013). Teacher self-efficacy and its influence on student motivation. Dissertation Abstracts International Section A: Humanities and Social Sciences, 73(12-A(E)). http://ezproxy.library.uvic.ca/login?url=http://search.ebscohost.com/login.aspx?direct=true\&db=psyh\&A $\mathrm{N}=$ 2013-99111-268\&site=ehost-live\&scope=site

Friedmann, N., \& Rusou, D. (2015). Critical period for first language: The crucial role of language input during the first year of life. In Current Opinion in Neurobiology. https://doi.org/10.1016/j.conb.2015.06.003

Greimel, H. (2015, July). Honda to make English official language by 2020. Automotive News. https://www.autonews.com/article/20150703/OEM/150709942/honda-to-make-english-officiallanguage-by-2020

Hartshorne, J. K., Tenenbaum, J. B., \& Pinker, S. (2018). A critical period for second language acquisition: Evidence from 2/3 million English speakers. Cognition. https://doi.org/10.1016/j.cognition.2018.04.007

Hu, B. Y., Fan, X., Yang, Y., \& Neitzel, J. (2017). Chinese pre-school teachers' knowledge and practice of teacherchild interactions: The mediating role of teachers' beliefs about children. Teaching and Teacher Education. https://doi.org/10.1016/j.tate.2016.12.014

Hu, R. (2016). The Age Factor in Second Language Learning. Theory and Practice in Language Studies, 6(11), 2164. https://doi.org/10.17507/tpls.0611.13

Ismail, F. L. M. @, Ismail, A., Aziz, M. A. A., Aziz, S. A., Sharom, N. Q., \& Ramlan, S. R. (2018). Service Quality of Public Pre-school Education in Malaysia: Perceptions of Parents. Jurnal Sains Insani.

Kaur, N., Haron, N. I., \& Mohd Radzi, N. A. (2019). Malaysian University English Test: A Comic Approach to a Serious Subject Matter. In Proceedings of the Second International Conference on the Future of ASEAN (ICOFA) 2017 - Volume 1. https://doi.org/10.1007/978-981-10-8730-1_28

Klassen, R. M., Durksen, T. L., \& Tze, V. M. C. (2020). Teachers' Self-Efficacy Beliefs. In Teacher Motivation. https://doi.org/10.4324/9780203119273-7

Krejcie, R. V., \& Morgan, D. W. (1970). Determining Sample Size for Research Activities. Educational and Psychological Measurement. https://doi.org/10.1177/001316447003000308

Lomas, L., \& Clarke, D. (2016). Changes in Teachers' Knowledge and Beliefs about Mathematics and Mathematics Teaching: A Case Study. Proceedings of the 39th Annual Conference of the Mathematics Education Research Group of Australasia, 391-398. https://files.eric.ed.gov/fulltext/ED572325.pdf

Majzub, R. M. (2013). Critical Issues in Pre-school Education in Malaysia. Recent Advances in Educational Technologies.

Malaysia Education Blueprint, M. (2013). Malaysia Education Blueprint 2013 - 2025. Education. https://doi.org/10.1016/j.tate.2010.08.007

Malaysian Examinations Council. (2016). Malaysian University English Test (MUET). Batu Caves: Percetakan Warni, http://scholar.google.com/scholar?hl=en\&btnG=Search\&q=intitle:Malaysian+university+english+test\#4

Melitz, J. (2016). English as a global language. In The Palgrave Handbook of Economics and Language. https://doi.org/10.1007/978-1-137-32505-1

Mohamed, A. H. H., \& Al-Qaryouti, I. A. (2016). The association between pre-school teachers' beliefs and practices about developmentally appropriate practices. Early Child Development and Care, 186(12), 1972-1982. https://doi.org/10.1080/03004430.2016.1146260

Mohd. Hamzah, M. I., \& Attan, N. (2007). Tahap Kesediaan Guru Sains Dalam Penggunaan Teknologi Maklumat Berasaskan Komputer Dalam Proses Pengajaran Dan Pembelajaran. Jurnal Teknologi. https://doi.org/10.11113/jt.v46.307

Nafissi, Z., \& Shafiee, Z. (2019). Teachers ' roles in early childhood English language pedagogy: beliefs of kindergarten English language teachers. Journal of Early Childhood Teacher Education, Q0), 1-19. https://doi.org/10.1080/10901027.2019.1647479

Nair, S. M., Hanafi, Z., \& Yassin, S. M. (2017). Do Pre-school Teachers' Education Affect their Classroom Practices and Career Paths? International Journal of Education and Practice. https://doi.org/10.18488/journal.61.2017.56.88.94 
Othman, J. (2019). Reform in Assessment: Teachers' Beliefs and Practices. Journal of Teaching English for Specific and Academic Purposes, 6, 501. https://doi.org/10.22190/jtesap1803501o

Othman, J., \& Kiely, R. (2016). Preservice teachers' beliefs and practices in teaching english to young learners. Indonesian Journal of Applied Linguistics. https://doi.org/10.17509/ijal.v6i1.2661

Peter, H. W., \& Chomsky, N. (1968). Aspects of the Theory of Syntax. The Modern Language Review. https://doi.org/10.2307/3722650

Rashid, R. A. B., Rahman, S. B. A., \& Yunus, K. (2017). Reforms in the policy of English language teaching in Malaysia. Policy Futures in Education. https://doi.org/10.1177/1478210316679069

Reber, R., \& Greifeneder, R. (2017). Processing Fluency in Education: How Metacognitive Feelings Shape Learning, Belief Formation, and Affect. Educational Psychologist. https://doi.org/10.1080/00461520.2016.1258173

Rethinasamy, S., \& Chuah, K. M. (2011). The Malaysian university English test (MUET) and its use for placement purposes: A predictive validity study. Electronic Journal of Foreign Language Teaching. https://doi.org/10.2139/ssrn.2146007

Sani, R. (2017, December 15). All-round concerted efforts needed. New Straits Times. https://www.nst.com.my/news/2017/03/117441/all-round-concerted-efforts-needed

Saunders, M., Lewis, P., \& Thornhill, A. (2016). Research Methods for Business Students (7th ed.). Pearson Education Limited.

Schlueter, A. L. (2019). Learning English for Young Learners "The Aspect of Intercultural Dimension, Diversity Arts and Media in the Early Foreign Language Education." 276(Icoelt 2018), 229-233. https://doi.org/10.2991/icoelt-18.2019.33

Sekaran, U., \& Bougie, R. (2016). Research methods for business : a skill-building approach / Uma Sekaran and Roger Bougie. In Nucleic Acids Research.

Shafa. (2015). Teori Pemerolehan Bahasa dan Implikasinya dalam Pembelajaran. Jurusan Tarbiyah STAIN. https://doi.org/10.21093/di.v12i2.61

Ting, S. H., Marzuki, E., Chuah, K. M., Misieng, J., \& Jerome, C. (2017). Employers' views on the importance of english proficiency and communication skill for employability in Malaysia. Indonesian Journal of Applied Linguistics. https://doi.org/10.17509/ijal.v7i2.8132

United Nations Development Programme. (2019). Human Development Report 2019: Inequalities in Human Development in the 21st Century: Briefing note for countries on the 2019 Human Development Report. http://hdr.undp.org/sites/all/themes/hdr_theme/country-notes/NZL.pdf

Vosniadou, S. (2019). Teachers' beliefs and knowledge. In Problem Solving for Teaching and Learning: A Festschrift for Emeritus Professor Mike Lawson. https://doi.org/10.4324/9780429400902-8

$\mathrm{Xu}, \mathrm{L}$. (2012). The role of teachers' beliefs in the language teaching-learning process. Theory and Practice in Language Studies. https://doi.org/10.4304/tpls.2.7.1397-1402

Yang, J. (2019). Understanding Chinese language teachers' beliefs about themselves and their students in an English context. System. https://doi.org/10.1016/j.system.2018.10.014

Zee, M., \& Koomen, H. M. Y. (2016). Teacher Self-Efficacy and Its Effects on Classroom Processes, Student Academic Adjustment, and Teacher Well-Being: A Synthesis of 40 Years of Research. Review of Educational Research. https://doi.org/10.3102/0034654315626801 